\title{
Source analysis of volatile organic compounds by positive matrix factorization in urban and rural environments in Beijing
}

\author{
Zibing Yuan, ${ }^{1,2}$ Alexis Kai Hon Lau, ${ }^{1,2}$ Min Shao, ${ }^{3}$ Peter K. K. Louie, ${ }^{4}$ \\ Shaw Chen Liu, ${ }^{5}$ and Tong $\mathrm{Zhu}^{3}$ \\ Received 24 September 2008; revised 16 February 2009; accepted 15 June 2009; published 28 August 2009.
}

[1] This paper applies advance receptor model positive matrix factorization (PMF) source analysis to 1-h resolution VOC data collected at Yufa (rural site) and Peking University, or PKU (urban site), in Beijing. A range of major VOC sources was identified, including vehicle emissions, liquefied petroleum gas, coal combustion, and biogenic emissions. Vehicle activities contributed approximately $62 \%$ of VOC loading and $55 \%$ of ozone forming potential at the PKU site, compared to $38 \%$ of VOC loading and $42 \%$ of ozone forming potential at Yufa. These results indicate that the control of vehicle emissions is essential to alleviating VOC pollution, particularly in urban Beijing. We found that VOC emission strengths are relatively consistent throughout the day in the rural area; variation of mixing height therefore is a controlling factor for ground-level VOC concentration. In the urban area, both vehicle activity and variation of mixing height strongly impact VOC levels. Local sources within Beijing appeared to contribute most of the VOCs recorded at both urban and rural areas. However, as some of the VOC species are quite reactive, VOC emitted from distant sources would have been depleted during transportation, concurrent with the formation of secondary pollutants such as ozone and sulfate. Such depletion would mean that this source apportionment analysis would tend to overestimate the ozone forming capacity of local VOC sources compared to emissions from distant sources. Nevertheless, this study illustrates that high-resolution VOC measurements, especially those with a sampling frequency on the scale of less than 1 day, combined with PMF, can make a strong contribution to our understanding of pollutant emissions and transport characteristics and is a useful tool with which to formulate effective pollution control strategies.

Citation: Yuan, Z., A. K. H. Lau, M. Shao, P. K. K. Louie, S. C. Liu, and T. Zhu (2009), Source analysis of volatile organic compounds by positive matrix factorization in urban and rural environments in Beijing, J. Geophys. Res., 114, D00G15, doi:10.1029/2008JD011190.

\section{Introduction}

[2] It is well established that both local and regional sources contribute significantly to the air pollution in Beijing in August. Tang [2004] concluded that about $40 \%$ of the regional contribution of ozone came from cities and provinces south of Beijing on an annual average basis. More specifically, Streets et al. [2007] by applying Model-3/ CMAQ model estimated that during ozone episodes in summer, regional contribution to the ground-level ozone in Beijing could range between 35 and $60 \%$. During the same

\footnotetext{
${ }^{1}$ Environmental Central Facility, Institute for the Environment, Hong Kong University of Science and Technology, Hong Kong.

${ }^{2}$ Atmospheric Research Center, HKUST Fok Ying Tung Graduate School, Guangzhou, China.

${ }^{3}$ College of Environmental Sciences and Engineering, Peking University, Beijing, China.

${ }^{4}$ Hong Kong Environmental Protection Department, Hong Kong.

${ }^{5}$ Research Center for Environmental Changes, Academia Sinica, Taipei, Taiwan.

Copyright 2009 by the American Geophysical Union. 0148-0227/09/2008JD011190\$09.00
}

period, regional contribution to $\mathrm{PM}_{2.5}$ in urban Beijing was estimated to be $34 \%$ on average.

[3] VOC is an active precursor of ozone and secondary aerosols. Various studies [e.g., Yao et al., 2003; Streets et al., 2007] have reported that Beijing suffers from serious ozone and secondary PM pollution in summer, which coincided with the timeframe for the 2008 Olympic games held in Beijing. In addition, a previous study has identified $\mathrm{VOC}$ as the key precursor for ozone production in urban Beijing [Xu et al., 2008]. The implication of this finding is that, at least if considered as a stopgap measure, VOC should be targeted to help alleviate the ozone problem. VOC, however, is a common term for a family of reactive organic compounds which have a wide variety of emission sources. To date, data on the chemical composition of ambient VOCs, VOC emission profiles, and spatial and temporal distributions of most VOC sources in Beijing are limited [Shao et al., 2005; Huang et al., 2008], which further complicates efforts to formulate effective ozone and PM control strategies. Regionally, VOC species are transformed, and probably depleted, during the transport process, along with which ozone and secondary PM are produced. Information on the 
relative contributions of local and regional VOC sources to Beijing is urgently needed for an in-depth understanding of ozone and fine particle pollution.

[4] The positive matrix factorization (PMF) model employed in this work is a mature statistical analysis method that can apportion the ambient concentration data into sources via identifying the intrinsic characteristics of the data, and at the same time limiting all the elements in the factor score (source profiles) and the factor loading (source contributions) matrix to be positive. It is therefore especially useful in environmental source analysis. The main uncertainty of the PMF result is associated with the change of VOC source profiles during transportation of air mass. The more reactive species will be oxidized at a faster rate, hence the more distant the emission sources from the monitoring receptor, the more enriched the unreactive VOC portion in the source profile is. Na and Kim [2007] provided a first-order decay adjustment by assuming the travel time of an air mass is inversely proportional to the wind speed, with the actual magnitude estimated from sensitivity studies. They found that incorporating the reaction loss helps to better fit the source profiles to the ambient VOC concentration in Chemical Mass Balance (CMB) calculations. They also concluded that the reaction loss does not significantly affect the estimation of source contributions. This approach makes a basic assumption that the sources are located approximately equal distance to the receptor, which is not necessarily realistic. Therefore, considering the conclusion that decay adjustment is not sensitive to the estimation of source contributions, a no-decay-adjust mechanism is imposed on the VOC observations in this study for source analysis. Thus, source profiles from PMF could be regarded as the average profile characteristics during the entire observation period.

[5] There are very few papers reporting PMF application for VOC source identification and apportionment in China. Song et al. [2007] reported the first-ever attempt of applying PMF to the subhourly speciated data set at the Peking University (PKU) site in Beijing. Eight major sources, namely natural gas, biogenic emission, painting, petrochemistry, liquid petroleum gas (LPG), diesel exhaust, and two gasoline exhaust sources were identified and their contributions quantified. They concluded that gasoline-related emissions were the single largest VOC contributor to PKU, accounting for $52 \%$ of the total VOC level. This was followed by petrochemical sources (20\%) and LPG (11\%). They estimated that gasoline, petrochemical, and biogenic sources were the major contributors to ozone formation potentials. The results from the PMF model were compared with the source apportionments by other receptor models using the same data set obtained in Beijing in the summer of 2005 [Song et al., 2008]. The source contributions were similar from these models though, it was found that the discrepancies were mainly due to the differences of the VOC source profiles. As these analyses were all done at an urban site (PKU) in Beijing, the spatial representativeness of VOC sources needs further investigation.

[6] In this study, we apply PMF for VOC source apportionment by using speciated VOC data collected at both Yufa and PKU, to identify the major VOC sources that contribute to ambient VOC levels in Beijing. We also investigate diurnal variation characteristics and general directions of all identified sources, and estimate the source-specific ozone forming potentials in the summer of 2006 at both sites.

\section{Sample Measurement and Data Preprocessing 2.1. Monitoring Sites}

[7] Simultaneous online measurements of VOC species were conducted at the PKU and Yufa sites from 15 August to 10 September 2006. Satellite images show that the worst air pollution in the North China Plain for the month of August in the past 6 years was recorded in August 2006 (Figure 1). A more detailed map shows the locations of the two sampling sites in Beijing Municipality (Figure 2). The PKU site is located in a commercial and residential area in the northwest part of urban Beijing. The Yufa site is located approximately $50 \mathrm{~km}$ southwest to the Beijing city center near the border of Beijing Municipality and Hebei Province. The town has population of 47,000 , and the main economic activities are cultivation and agriculture. There is a state highway at $1.5 \mathrm{~km}$ east of the site, and the vehicular emissions there may sometimes influence the site. The $\mathrm{NO}_{\mathrm{x}}$ levels measured at Yufa site ranged from 8 to 90 ppbv with the average at 16 ppbv. Located directly in the pollution band shown in Figure 1, the Yufa site is a representative site for rural areas with low local anthropogenic VOC emissions. Emissions from urban Beijing (local sources) and common summertime long-range transport (regional sources) occur from roughly opposite directions (northeast versus southwest) at Yufa, making Yufa a good candidate to distinguish the local and regional sources impacting Beijing. On the other hand, most of the human activities thus local anthropogenic emissions are from south or southeast of PKU station, while the regional transport during August also mainly originates from southeast or southwest. Therefore, the local/regional differentiation at PKU is expected to be relatively ambiguous in comparison with Yufa.

\subsection{VOC Measurement}

[8] Subhourly VOC measurement at Yufa was collected by a Syntech Spectras GC955 (Synspec BV, Groningen, Netherlands). To encompass VOCs of a wide range of volatility within each analysis, this instrument was designed as a double gas chromatograph (GC), with one section dedicated to the trapping, separating and detecting of $\mathrm{C}_{2}-\mathrm{C}_{5}$ hydrocarbons. This section combined an analytical $\mathrm{Al}_{2} \mathrm{O}_{3} / \mathrm{KCl}$ PLOT column with a Flame Ionization Detector (FID) and a Photo Ionization Detector (PID). The other section was for the monitoring of $\mathrm{C}_{6}$ to $\mathrm{C}_{10}$ hydrocarbons, using a standard DB-1 column and a PID detector. The equipment sampled for around $20 \mathrm{~min}$ in each 30 -min period, and an analysis of the previous sample was completed every $30 \mathrm{~min}$ in parallel.

[9] Hourly VOC measurements at PKU were collected by GC/FID (Agilent 6890, Hewlett-Packard, Palo Alto, CA) with a preconcentrator [Wang et al., 2004]. Similar to the GC955, the system used dual traps and dual columns $\left(\mathrm{Al}_{2} \mathrm{O}_{3}\right.$ PLOT and DB-1 column) to simultaneously analyze both low and high boiling point compounds with each injection. Both sections were analyzed by a FID detector. The equipment sampled for around $30 \mathrm{~min}$ in each $60-\mathrm{min}$ 
SEC(Dry) Monthly Average August 2003 (min 0.11, max 0.40)

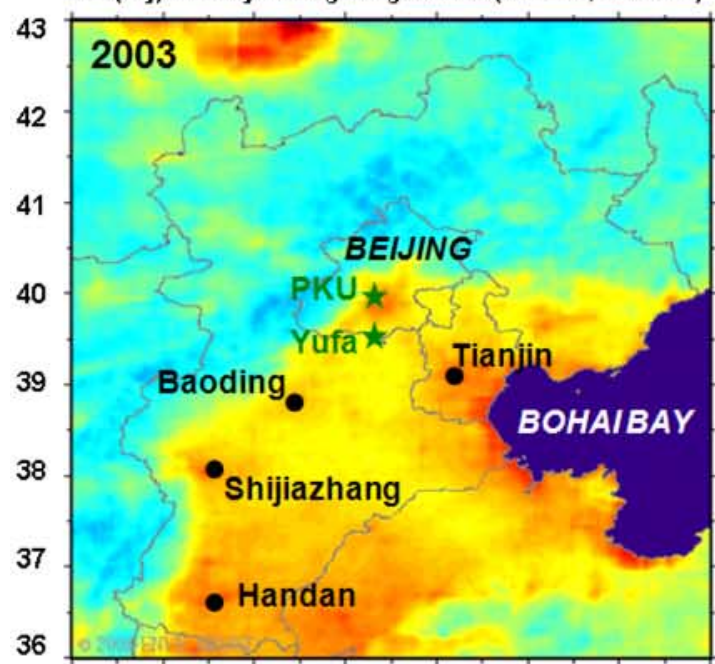

SEC(Dry) Monthly Average August 2005 (min 0.10, $\max 0.44)$

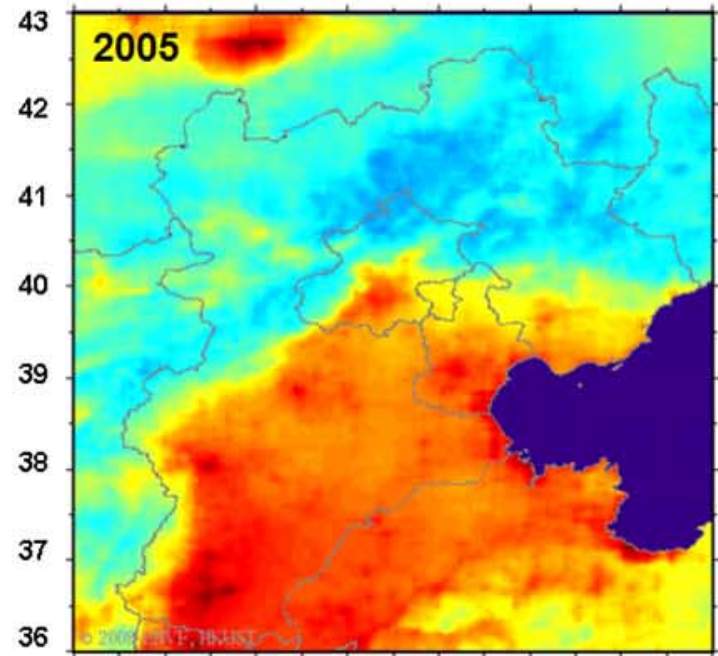

SEC(Dry) Monthly Average August 2007 (min 0.17, max 0.37)

43

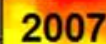

42

${ }^{41}$

40

39

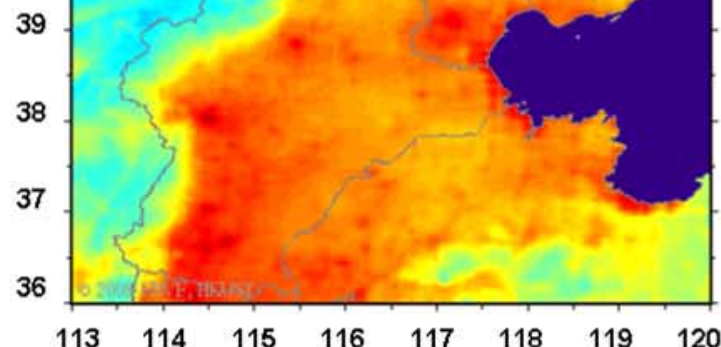

SEC(Dry) Monthly Average August 2004 (min 0.18, max 0.34)

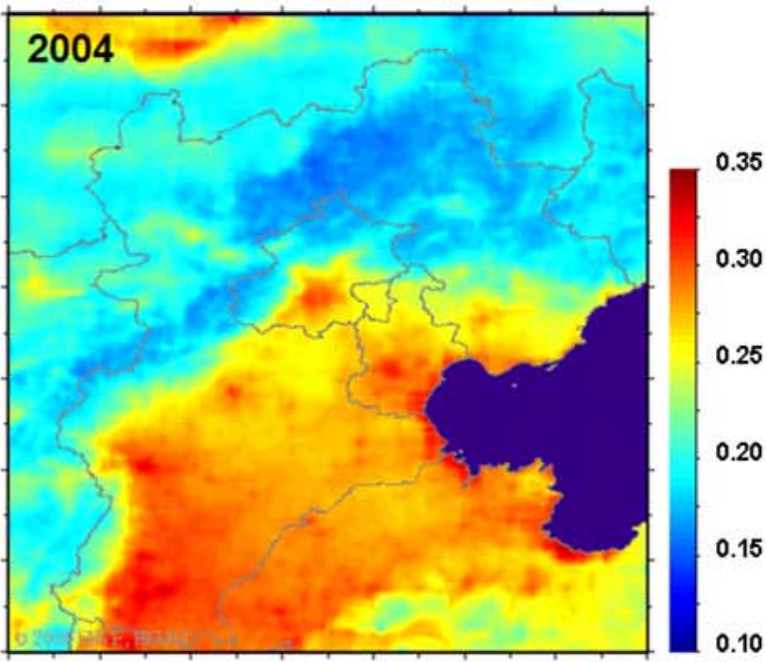

SEC(D ry) Monthly Average August 2006 (min 0.16, max 0.35)

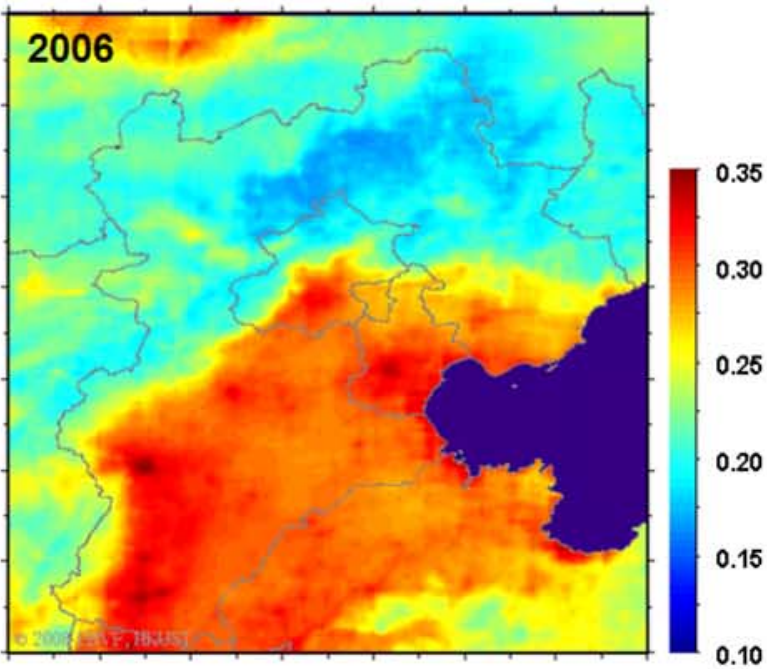

SEC(Dry) Monthly Average August 2008 (min 0.13 , max 0.39)

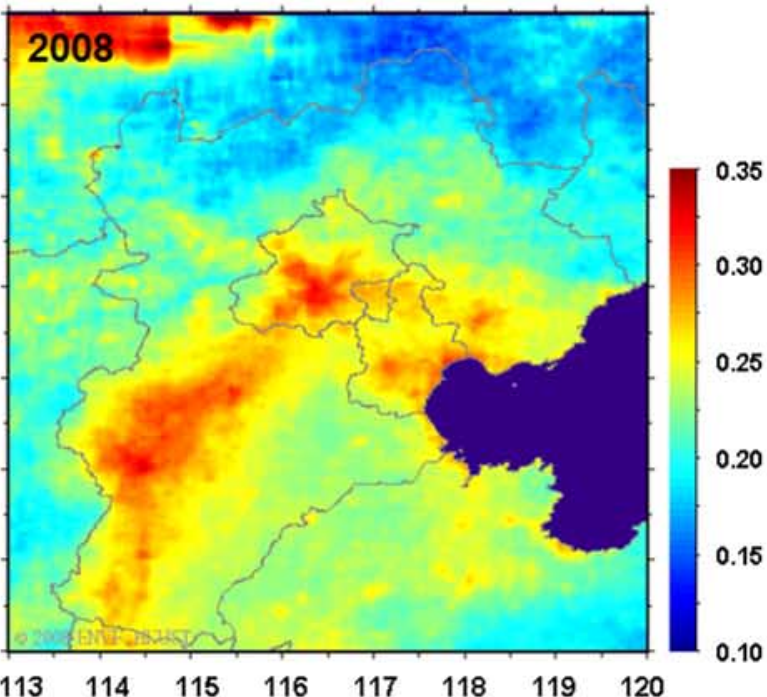

Figure 1. MODIS observation of monthly average surface extinction coefficient in August in the North China Plain from 2003 to 2008. The scale in the $x$ and $y$ axes represents latitude/longitude. 


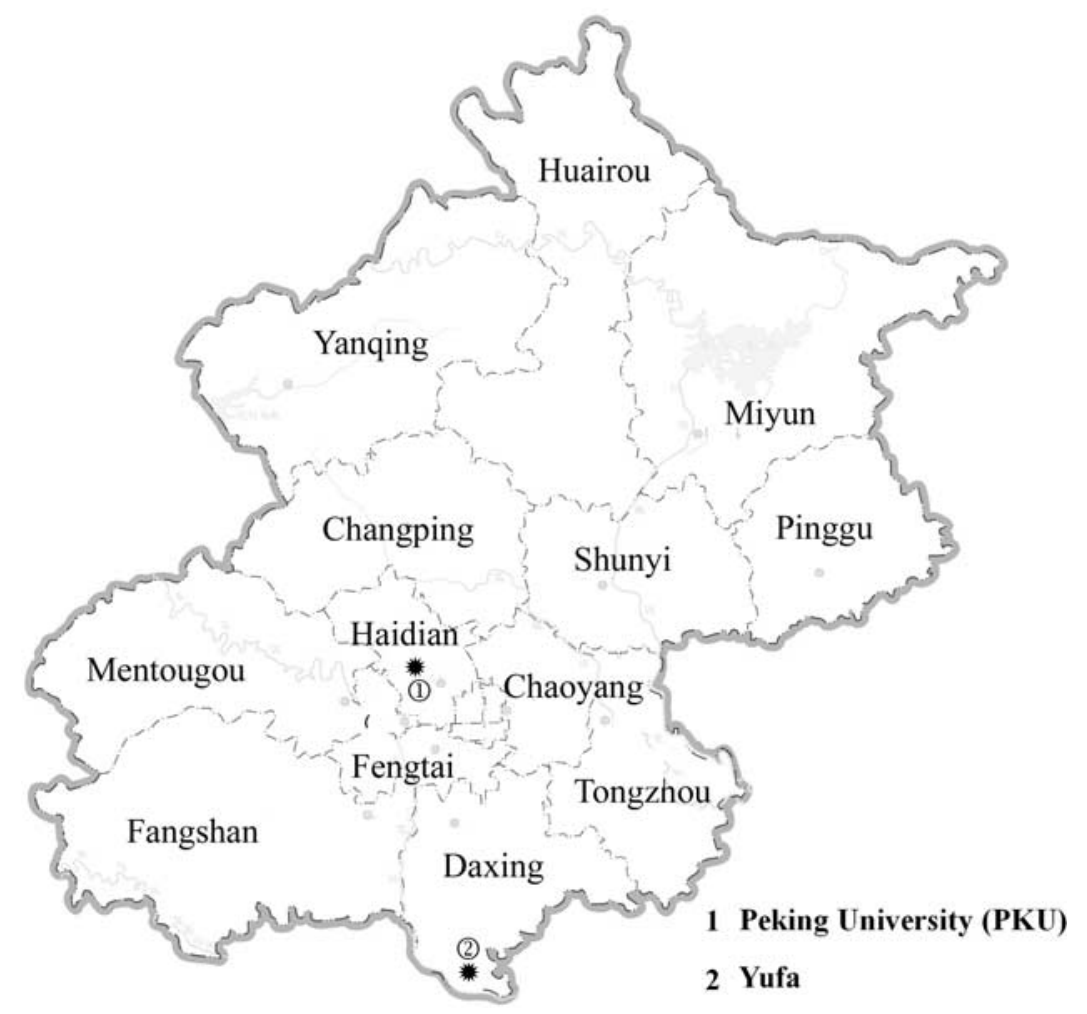

Figure 2. Map of intensive measurement sites in Beijing Municipality. The longitude of Beijing ranges between $115^{\circ} 25^{\prime} \mathrm{E}$ and $117^{\circ} 30^{\prime} \mathrm{E}$ and the latitude ranges between $39^{\circ} 26^{\prime} \mathrm{N}$ and $41^{\circ} 03^{\prime} \mathrm{N}$.

period, and an analysis for the previous sample was completed every $30 \mathrm{~min}$ in parallel.

[10] The precision of both systems was examined by repeatedly injecting a standard mixture containing 51 target species with concentrations in the range of 3 and $15 \mathrm{ppbv}$, made by Spectra Gases Company, NJ, USA. In general, the precision for $\mathrm{C}_{3}-\mathrm{C}_{12}$ VOCs was below $3 \%$. Linearity was also tested by trapping a series of the same standard mixture of various volumes. Most compounds exhibited linearity with correlation coefficients above 0.995 . Minimum detection limit (MDL) is species-specific, ranging from 0.005 for 3-methylhaxane to 0.098 for n-butane. A detailed description of the analytical setup and QA/QC procedures can be found elsewhere [Xie et al., 2008; Wang et al., 2004].

\subsection{Data Pretreatment}

[11] In the PMF application, the uncertainty of species concentration was determined as the sum of $5 \%$ of the VOC concentration and two units of the least significant digit of the concentration data [Paatero, 2000]. The error model of -14 was applied following the PMF developer's recommendation [Paatero, 2000]. To avoid any unrealistic data distorting the source analysis result, a simple rejection rule was applied to the large data set. First, if more than $25 \%$ of the samples for a particular species are missing or below MDL, the species would be rejected from the analysis. Subsequently, the samples either with concentration data missing or below MDL were also rejected. Four-hundredthirty-six subhourly samples $(86 \%$ of total 509 samples measured) and 21 VOC species at PKU, and 949 hourly samples ( $89 \%$ of total 1062 samples measured) and 17 VOC species at Yufa, were retained after this set of operations.

\section{Source Identification \\ 3.1. Determination of the Number of Factors and Source Category}

[12] The determination of the number of factors is a critical step for receptor-based source apportionment methods, especially for bilinear methods, where very little prior knowledge about the sources is assumed. Mathematically perfect matrix decompositions into scores and loadings do not guarantee the solutions are physically meaningful. Here, we followed the philosophy that an appropriate number of factors have to be determined by means of interpretability and physical meaningfulness as proposed earlier [e.g., Li et al., 2004; Lanz et al., 2007]. To help accurately identify the source categories, simultaneously monitored air pollutants, i.e., $\mathrm{SO}_{2}, \mathrm{CO}$ and $\mathrm{NO}_{\mathrm{x}}$, were added to be fit in the PMF model. Source categories were determined on the basis of the degrees of abundances of each species in the derived sources.

\subsection{PKU Site}

[13] At PKU, seven sources were identified. They were gasoline exhaust, evaporated and liquid gasoline, diesel exhaust, liquefied petroleum gas (LPG), coal combustion, paint and industrial coating, and biogenic emission. Table 1 lists the actual source profiles and the corresponding uncertainties. Figure 3 illustrates the explained variations (EVs) of all the identified sources. The quantity of the EV indicates how important each factor element is in explaining 
Table 1. Source Profiles and Uncertainties at PKU Derived by $\mathrm{PMF}^{\mathrm{a}}$

\begin{tabular}{|c|c|c|c|c|c|c|c|}
\hline & $\begin{array}{l}\text { Gasoline } \\
\text { Exhaust }\end{array}$ & $\begin{array}{l}\text { Evaporated and } \\
\text { Liquid Gasoline }\end{array}$ & $\begin{array}{c}\text { Diesel } \\
\text { Exhaust }\end{array}$ & LPG & $\begin{array}{c}\text { Coal } \\
\text { Combustion }\end{array}$ & $\begin{array}{l}\text { Paint and } \\
\text { Industrial } \\
\text { Coating }\end{array}$ & $\begin{array}{l}\text { Biogenic } \\
\text { Emission }\end{array}$ \\
\hline Propane & $3.19 \pm 0.43 \%$ & $8.70 \pm 0.34 \%$ & $5.22 \pm 0.83 \%$ & $23.86 \pm 0.75 \%$ & $19.29 \pm 1.15 \%$ & $0.73 \pm 0.60 \%$ & $0.01 \pm 0.38 \%$ \\
\hline Isobutane & $3.51 \pm 0.53 \%$ & $14.62 \pm 0.42 \%$ & $4.86 \pm 1.02 \%$ & $22.35 \pm 0.93 \%$ & $2.57 \pm 1.34 \%$ & $8.59 \pm 0.75 \%$ & $0.08 \pm 1.53 \%$ \\
\hline n-Butane & $3.74 \pm 0.57 \%$ & $21.14 \pm 0.46 \%$ & $2.99 \pm 1.10 \%$ & $15.75 \pm 0.98 \%$ & $3.96 \pm 1.46 \%$ & $6.14 \pm 0.80 \%$ & $0.29 \pm 1.87 \%$ \\
\hline Isopentane & $15.23 \pm 0.68 \%$ & $19.46 \pm 0.93 \%$ & $9.89 \pm 1.34 \%$ & $6.25 \pm 0.29 \%$ & $7.78 \pm 1.70 \%$ & $2.07 \pm 0.92 \%$ & $1.83 \pm 2.16 \%$ \\
\hline n-Pentane & $8.72 \pm 0.36 \%$ & $7.23 \pm 0.24 \%$ & $4.10 \pm 0.62 \%$ & $2.99 \pm 0.26 \%$ & $4.19 \pm 0.77 \%$ & $1.89 \pm 0.42 \%$ & 0 \\
\hline Isoprene & $0.80 \pm 0.12 \%$ & $0.04 \pm 0.07 \%$ & $1.82 \pm 0.28 \%$ & $0.58 \pm 0.18 \%$ & $0.31 \pm 0.30 \%$ & $0.04 \pm 0.14 \%$ & $64.63 \pm 0.72 \%$ \\
\hline 2-Methylpentane & $5.59 \pm 0.20 \%$ & $1.12 \pm 0.11 \%$ & $3.63 \pm 0.31 \%$ & $2.77 \pm 0.13 \%$ & $1.73 \pm 0.39 \%$ & $0.59 \pm 0.21 \%$ & $1.82 \pm 0.53 \%$ \\
\hline 3-Methylpentane & $4.70 \pm 0.18 \%$ & $1.09 \pm 0.10 \%$ & $3.31 \pm 0.28 \%$ & $2.41 \pm 0.12 \%$ & $2.91 \pm 0.35 \%$ & $0.51 \pm 0.19 \%$ & $0.45 \pm 0.47 \%$ \\
\hline n-Hexane & $7.68 \pm 0.38 \%$ & $4.14 \pm 0.23 \%$ & $5.19 \pm 0.59 \%$ & $3.50 \pm 0.25 \%$ & $8.81 \pm 0.77 \%$ & $3.73 \pm 0.41 \%$ & $0.99 \pm 1.01 \%$ \\
\hline 2-Methylhexane & $3.65 \pm 0.12 \%$ & $0.49 \pm 0.07 \%$ & $2.44 \pm 0.20 \%$ & $1.46 \pm 0.08 \%$ & $1.89 \pm 0.24 \%$ & $0.58 \pm 0.13 \%$ & $0.32 \pm 0.33 \%$ \\
\hline 3-Methylhexane & $4.10 \pm 0.17 \%$ & $1.52 \pm 0.10 \%$ & $2.62 \pm 0.27 \%$ & $1.64 \pm 0.11 \%$ & $2.80 \pm 0.34 \%$ & $1.39 \pm 0.18 \%$ & $1.23 \pm 0.46 \%$ \\
\hline n-Heptane & $2.90 \pm 0.10 \%$ & $0.69 \pm 0.07 \%$ & $2.56 \pm 0.18 \%$ & $0.86 \pm 0.07 \%$ & $1.74 \pm 0.21 \%$ & $1.02 \pm 0.12 \%$ & $0.00 \pm 0.07 \%$ \\
\hline n-Octane & $1.31 \pm 0.06 \%$ & $0.18 \pm 0.03 \%$ & $2.48 \pm 0.10 \%$ & $0.49 \pm 0.04 \%$ & $0.84 \pm 0.11 \%$ & $0.69 \pm 0.06 \%$ & $0.17 \pm 0.16 \%$ \\
\hline n-Nonane & $0.48 \pm 0.04 \%$ & $0.03 \pm 0.03 \%$ & $5.02 \pm 0.11 \%$ & $0.08 \pm 0.06 \%$ & $0.27 \pm 0.09 \%$ & $0.63 \pm 0.05 \%$ & $1.31 \pm 0.13 \%$ \\
\hline n-Decane & $0.27 \pm 0.04 \%$ & $0.14 \pm 0.03 \%$ & $5.87 \pm 0.12 \%$ & $0.04 \pm 0.06 \%$ & $0.03 \pm 0.09 \%$ & $0.93 \pm 0.05 \%$ & $1.47 \pm 0.13 \%$ \\
\hline Benzene & $9.14 \pm 0.47 \%$ & $8.10 \pm 0.34 \%$ & $7.07 \pm 0.92 \%$ & $1.78 \pm 0.76 \%$ & $21.70 \pm 1.23 \%$ & $5.70 \pm 0.61 \%$ & $3.61 \pm 1.60 \%$ \\
\hline Toluene & $18.25 \pm 0.67 \%$ & $4.49 \pm 0.50 \%$ & $11.90 \pm 1.34 \%$ & $9.55 \pm 1.12 \%$ & $18.06 \pm 1.65 \%$ & $14.91 \pm 0.92 \%$ & 0 \\
\hline Ethylbenzene & $1.56 \pm 0.22 \%$ & $2.60 \pm 0.17 \%$ & $1.69 \pm 0.44 \%$ & $0.07 \pm 0.37 \%$ & $0.49 \pm 0.54 \%$ & $15.31 \pm 0.34 \%$ & $8.51 \pm 0.74 \%$ \\
\hline m,p-Xylene & $2.57 \pm 0.35 \%$ & $3.04 \pm 0.26 \%$ & $7.82 \pm 0.71 \%$ & $0.98 \pm 0.57 \%$ & $0.06 \pm 0.79 \%$ & $23.64 \pm 0.52 \%$ & $8.27 \pm 1.12 \%$ \\
\hline o-Xylene & $1.44 \pm 0.13 \%$ & $0.97 \pm 0.10 \%$ & $3.55 \pm 0.28 \%$ & $1.04 \pm 0.22 \%$ & $0.54 \pm 0.32 \%$ & $7.37 \pm 0.20 \%$ & $3.79 \pm 0.44 \%$ \\
\hline 1,2,4-Trimethylbenzene & $1.15 \pm 0.09 \%$ & $0.22 \pm 0.07 \%$ & $5.96 \pm 0.21 \%$ & $1.55 \pm 0.14 \%$ & $0.04 \pm 0.21 \%$ & $3.54 \pm 0.13 \%$ & $1.22 \pm 0.30 \%$ \\
\hline
\end{tabular}

${ }^{\mathrm{a}}$ Source profiles are expressed in volume percentage.

the total mass of the element. It is particularly powerful for identifying tracer species when the absolute amounts of chemical species show a significant difference.

[14] The first three sources are all related to vehicle activities. Source 1 is identified as gasoline exhaust on the basis of a significant presence of 3-methylpentane, n-hexane and 2-methylhexane, which are good tracers of gasoline exhaust [Watson et al., 2001]. As shown in Figure 3, $44 \%$ of 3 -methylpentane, $31 \%$ of n-hexane, and $48 \%$ of 2-methylhexane is associated with emissions from gasoline exhaust. Source 2 shows a dominance of isobutane (15\%), n-butane $(21 \%)$ and isopentane $(19 \%)$ in the source profile, and this is associated with the least amount of combustion produced $\mathrm{NO}$ and $\mathrm{NO}_{2}$, therefore this source is believed to be evaporated and liquid gasoline [Watson et al., 2001; Fujita, 2001]. Source 3 is characterized by significant n-nonane and n-decane, which are tracers for diesel exhaust [Watson et al., 2001; Song et al., 2007]. Forty-eight percent of n-nonane and $51 \%$ of n-decane are associated with diesel exhaust. In addition, the presence of light alkanes $\left(\mathrm{C}_{3}-\mathrm{C}_{4}\right)$ is much less than in gasoline exhaust.

[15] Source 4 is characterized by a significant amount of propane, isobutane and n-butane, typical tracers of emissions from LPG. LPG is an important domestic cooking and heating source in Beijing. In 2006, the annual use of LPG was around 415,000 tons, serving more than 1.9 million households [BMBS, 2007]. Unlike Hong Kong and Guangzhou however, LPG use in vehicles is not widespread in Beijing. All of the 2,300 buses and most of the 32,000 taxis once retrofitted with a bifuel supply system of gasoline/LPG engines now use gasoline as fuel, owing to the insufficient supply of LPG and the reduction of engine power when using LPG fuel. Less than $30 \%$ of retrofitted taxis are currently using LPG [Hao et al., 2006]. The annual consumption of LPG in the transport sector in 2006 was only 16,000 tons, a small fraction compared with the annual consumption of gasoline of 557,000 tons in the transport sector [BMBS, 2007].
[16] Source 5 is associated with over $93 \%$ of the total $\mathrm{SO}_{2}$ concentration measured, and therefore is believed to be from the coal combustion process. In Beijing's summertime, coal is mainly consumed by power plants for satisfying the soaring demand for electricity. However, as the emission point for power plants is generally on the order of a hundred meters high, and industrial use of coal has a high efficiency compared with household use, the power plant source contribution is believed to be small.

[17] Source 6 is rich in aromatic species (toluene, ethylbenzene, and xylenes, TEX) and has certain amounts of higher alkanes. This source is considered to be a composite of emissions from solvent use, industrial coatings, and architectural paints [Seila et al., 2001]. In the PMF derived source profile, toluene, ethylbenzene and xylenes account for $14.9 \%, 15.3 \%$ and $31.0 \%$ of the total mass, respectively. Although solvents from industrial and architectural sources are an important source of VOCs, there are only a few reported profiles and they exhibit a large discrepancy. For example, $78.3 \%$ toluene and $16.7 \%$ xylenes were reported in the source profile of product-type consumption in the New York City-State of New Jersey region [Scheff and Wadden, 1993], 38.4\% toluene and 55.9\% xylenes were reported in an industrial solvent source profile in Columbus, Ohio [Mukund et al., 1996], 62.7\% toluene and 27.0\% xylenes were reported from paint solvents emissions in Seoul, South Korea [Na et al., 2004], and 18.9\% toluene and $21.2 \%$ xylenes were reported from architectural and furnishing coating emissions in Beijing [Liu et al., 2005]. Therefore, only the information derived from the locationspecific measurements is qualified for result validation.

[18] Source 7 is distinguished by a significant presence of isoprene, an indicator of biogenic emissions, especially from broad-leafed trees [Kesselmeier and Staudt, 1999]. In the calculated source profile, isoprene accounts for $74.7 \%$ of the EV and $64.6 \%$ of the total mass. The latter percentage is expected to be an underestimate of the fresh emission profile due to the high reactivity of isoprene in the atmosphere. 

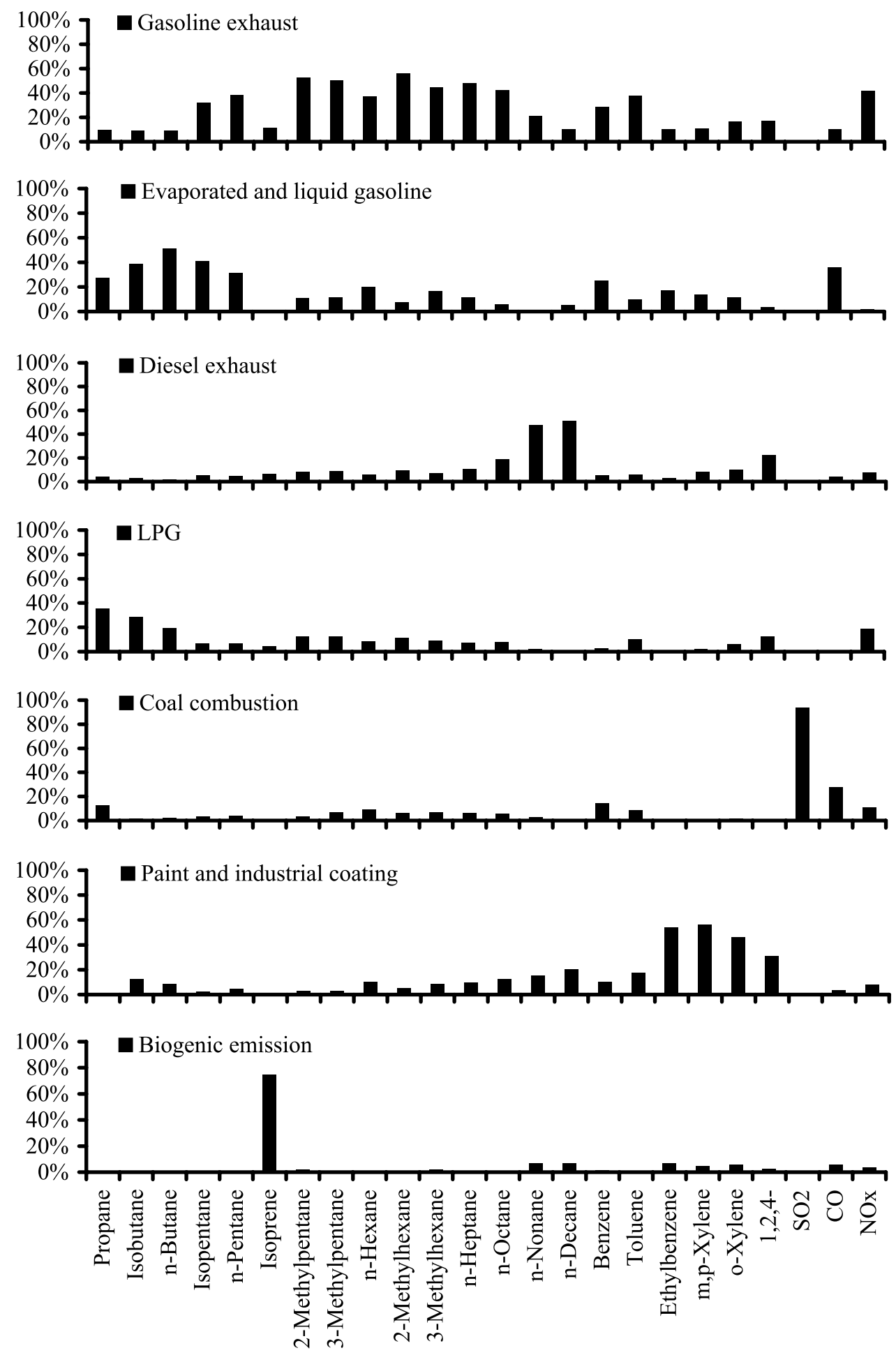

Figure 3. Explained variation of seven identified sources at PKU.

\subsection{Yufa Site}

[19] Table 2 lists the actual source profiles and the corresponding uncertainties at Yufa. Figure 4 illustrates the explained variations (EVs) of all identified sources. At Yufa, six sources are identified. The justifications for source identification are very similar to those for the PKU site. The only difference when compared with PKU is the combina- tion of gasoline exhaust and evaporated and liquid gasoline into a single source category. We postulate the main reason is they originate from the same area with respect to the station (i.e., the highway) and will converge frequent enough to make distinguishing them difficult. In addition, the temporal variation (e.g., diurnal and weekday/weekend) is also similar. Generally, if two sources come from the same direction, the 
Table 2. Source Profiles and Uncertainties at Yufa Derived by $\mathrm{PMF}^{\mathrm{a}}$

\begin{tabular}{|c|c|c|c|c|c|c|}
\hline & Gasoline Emission & Diesel Exhaust & LPG & Coal Combustion & $\begin{array}{c}\text { Paint and } \\
\text { Industrial Coating }\end{array}$ & Biogenic Emission \\
\hline Propane & $0.05 \pm 0.73 \%$ & $14.93 \pm 0.92 \%$ & $38.36 \pm 0.62 \%$ & $21.01 \pm 2.82 \%$ & $0.73 \pm 0.63 \%$ & $9.80 \pm 0.89 \%$ \\
\hline i-Butane & $2.53 \pm 0.56 \%$ & $15.69 \pm 0.63 \%$ & $17.18 \pm 0.33 \%$ & $1.56 \pm 1.79 \%$ & $0.02 \pm 0.30 \%$ & $5.28 \pm 0.53 \%$ \\
\hline n-Butane & $4.02 \pm 0.57 \%$ & $7.93 \pm 0.54 \%$ & $21.17 \pm 0.36 \%$ & $5.56 \pm 1.43 \%$ & $2.07 \pm 0.38 \%$ & $0.03 \pm 0.37 \%$ \\
\hline 1-Butene & $2.40 \pm 0.20 \%$ & $8.63 \pm 0.24 \%$ & $0.43 \pm 0.07 \%$ & $0.01 \pm 0.29 \%$ & $0.73 \pm 0.15 \%$ & $0.00 \pm 0.02 \%$ \\
\hline iso-Butene & $2.81 \pm 0.23 \%$ & $6.79 \pm 0.29 \%$ & $0.14 \pm 0.08 \%$ & $6.11 \pm 1.01 \%$ & $0.52 \pm 0.23 \%$ & $8.04 \pm 0.33 \%$ \\
\hline i-Pentane & $10.53 \pm 0.71 \%$ & $17.13 \pm 0.73 \%$ & $7.49 \pm 0.28 \%$ & $0.05 \pm 0.99 \%$ & $2.43 \pm 0.53 \%$ & $9.90 \pm 0.54 \%$ \\
\hline n-Pentane & $4.12 \pm 0.42 \%$ & $10.09 \pm 0.46 \%$ & $5.92 \pm 0.19 \%$ & $2.76 \pm 1.28 \%$ & $1.12 \pm 0.34 \%$ & $5.10 \pm 0.39 \%$ \\
\hline Isoprene & $0.27 \pm 0.12 \%$ & $0.02 \pm 0.15 \%$ & $0.02 \pm 0.04 \%$ & $2.69 \pm 0.70 \%$ & $0.06 \pm 0.16 \%$ & $42.05 \pm 0.55 \%$ \\
\hline 3-Methylpentane & $3.20 \pm 0.14 \%$ & $1.37 \pm 0.17 \%$ & $0.33 \pm 0.06 \%$ & $9.25 \pm 0.81 \%$ & $0.01 \pm 0.10 \%$ & $5.34 \pm 0.26 \%$ \\
\hline n-Hexane & $2.96 \pm 0.10 \%$ & $0.00 \pm 0.02 \%$ & $0.69 \pm 0.03 \%$ & $0.00 \pm 0.04 \%$ & $2.06 \pm 0.09 \%$ & $0.00 \pm 0.04 \%$ \\
\hline 2-Methylhexane & $7.67 \pm 0.22 \%$ & $2.40 \pm 0.22 \%$ & $0.00 \pm 0.04 \%$ & $0.52 \pm 0.64 \%$ & $1.95 \pm 0.21 \%$ & $1.31 \pm 0.22 \%$ \\
\hline n-Octane & $0.63 \pm 0.05 \%$ & $1.52 \pm 0.05 \%$ & $0.27 \pm 0.02 \%$ & $0.00 \pm 0.05 \%$ & $0.00 \pm 0.02 \%$ & $1.27 \pm 0.05 \%$ \\
\hline benzene & $30.51 \pm 1.58 \%$ & $0.02 \pm 0.55 \%$ & $5.35 \pm 0.51 \%$ & $38.25 \pm 5.61 \%$ & $17.21 \pm 1.51 \%$ & $9.82 \pm 1.73 \%$ \\
\hline toluene & $27.29 \pm 0.94 \%$ & $9.63 \pm 0.83 \%$ & $2.57 \pm 0.28 \%$ & $7.62 \pm 1.79 \%$ & $20.75 \pm 0.99 \%$ & $0.01 \pm 0.23 \%$ \\
\hline $\mathrm{m}$ - and p-xylene & $0.45 \pm 0.25 \%$ & $1.65 \pm 0.29 \%$ & $0.04 \pm 0.07 \%$ & $0.81 \pm 0.65 \%$ & $24.25 \pm 0.49 \%$ & $0.46 \pm 0.16 \%$ \\
\hline o-xylene & $0.14 \pm 0.07 \%$ & $0.65 \pm 0.08 \%$ & $0.02 \pm 0.02 \%$ & $0.05 \pm 0.14 \%$ & $9.29 \pm 0.15 \%$ & $0.24 \pm 0.03 \%$ \\
\hline Ethylbenzene & $0.44 \pm 0.21 \%$ & $1.55 \pm 0.27 \%$ & $0.02 \pm 0.07 \%$ & $3.75 \pm 0.69 \%$ & $16.82 \pm 0.42 \%$ & $1.35 \pm 0.18 \%$ \\
\hline
\end{tabular}

${ }^{\mathrm{a}}$ Source profiles are expressed in volume percentage.

temporal difference of two emission strengths can serve as another degree of freedom for separation.

\section{Estimation of Source Contributions}

[20] After normalizing the source profiles with respect to the total mass of each source, we obtained the absolute source contributions for each sample. Table 3 lists the average absolute source contribution and contribution percentage at PKU and Yufa. In order to make a comparison between the two sites, the source contributions from 15 major species that were measured at both sites are calculated. In total, the loading of these 15 VOC species at PKU (22.1 ppb) nearly doubles that of Yufa (12.5 ppb). Vehicle-related sources are the largest contributors at both sites, responsible for $62 \%$ of the ambient VOC at PKU and 38\% at Yufa. These large fractions provide a compelling reason for drastic vehicle emission control measures as a means for reducing VOCs in Beijing.

[21] It is interesting to note that VOCs emissions from gasoline-fueled vehicles, mainly passenger cars and minibuses, make the largest contribution $(57 \%)$, to the ambient VOC levels at the urban site, while diesel exhaust show a much smaller impact (5\%). The rural site has a different pattern. The absolute contribution of diesel exhaust (1.7 ppb) is slightly higher than that at PKU (1.2 ppb), making its contribution percentage moderately higher (14\%), although still less than that of gasoline emissions. Gasoline-related emissions show a significantly smaller influence $(25 \%)$ due to the lower traffic intensity of gasoline-powered vehicles at Yufa. The largest difference of sources between the two sites is from LPG. At Yufa, LPG contributed $4.6 \mathrm{ppb}$, accounting for $37 \%$ of ambient VOC level. This is contrasted by the contribution of $2.9 \mathrm{ppb}$ or $13 \%$ at PKU. Wind rose analysis in section 5 will reveal the direction of this significant source with respect to the Yufa site.

[22] The source apportionment results at PKU are generally similar to what Song et al. [2007] reported with the August 2005 data collected exactly at the same station. Gasoline-related contribution accounted for $57 \%$ of total VOC in August 2006, which is well in between the estimations of $52 \%$ by PMF [Song et al., 2007], and $64 \%$ by CMB
[Song et al., 2008]. This shows gasoline-related source consistently dominates the ambient VOC loading in Beijing. The large contribution fraction of vehicular sources is not unique in Beijing. We even found $82-87 \%$ contribution fraction from vehicle sources at traffic intersections of Delhi, India [Srivastava et al., 2005], and 80\% at an urban station in Los Angeles [Brown et al., 2007]. Table 4 summarizes the contribution percentages of vehicle-related sources to ambient VOC in different cities in the world.

[23] Source contribution from paint and industrial coating increased from 5\% in August 2005 to $16 \%$ in August 2006 at PKU. This was probably due to the fact that 2006 was the peak year with all the Olympic stadium and housing under construction. In our study we did not identify significant contribution from petrochemical industry owing to the absence of $\mathrm{C} 2$ compounds as source markers, but by combining $\mathrm{SO}_{2}$ data in the source apportionment analysis, we can identify a clear source of coal combustion, which should partly come from petrochemical industry, contributing around $6 \%$ of total VOC at PKU.

\section{Diurnal Variation of VOC Sources}

[24] Figure 5 shows the diurnal variation of all identified sources at PKU and Yufa. At Yufa, the variation pattern is relatively simple. All sources except biogenic emission exhibit a variation roughly inversely proportional to the variation of the mixing layer height. Guinot et al. [2006] reported that boundary layer height in August in Beijing displays low values at nighttime $(80 \pm 50 \mathrm{~m})$ and may develop irregularly from 300 to $3000 \mathrm{~m}$ during the day depends on weather conditions, generally reaching the maximum at 1500 local time. Therefore, the vertical-integrated source contributions at Yufa are considered relatively consistent throughout the day. As a result, variation of mixing height is a crucial factor controlling the ground-level VOC concentration at Yufa. For biogenic emissions, the source contribution is fairly consistent with sunlight intensity, peaking at 1500 local time (LT).

[25] At PKU, the diurnal variation of sources is quite different. The emission increase in gasoline exhaust in the 

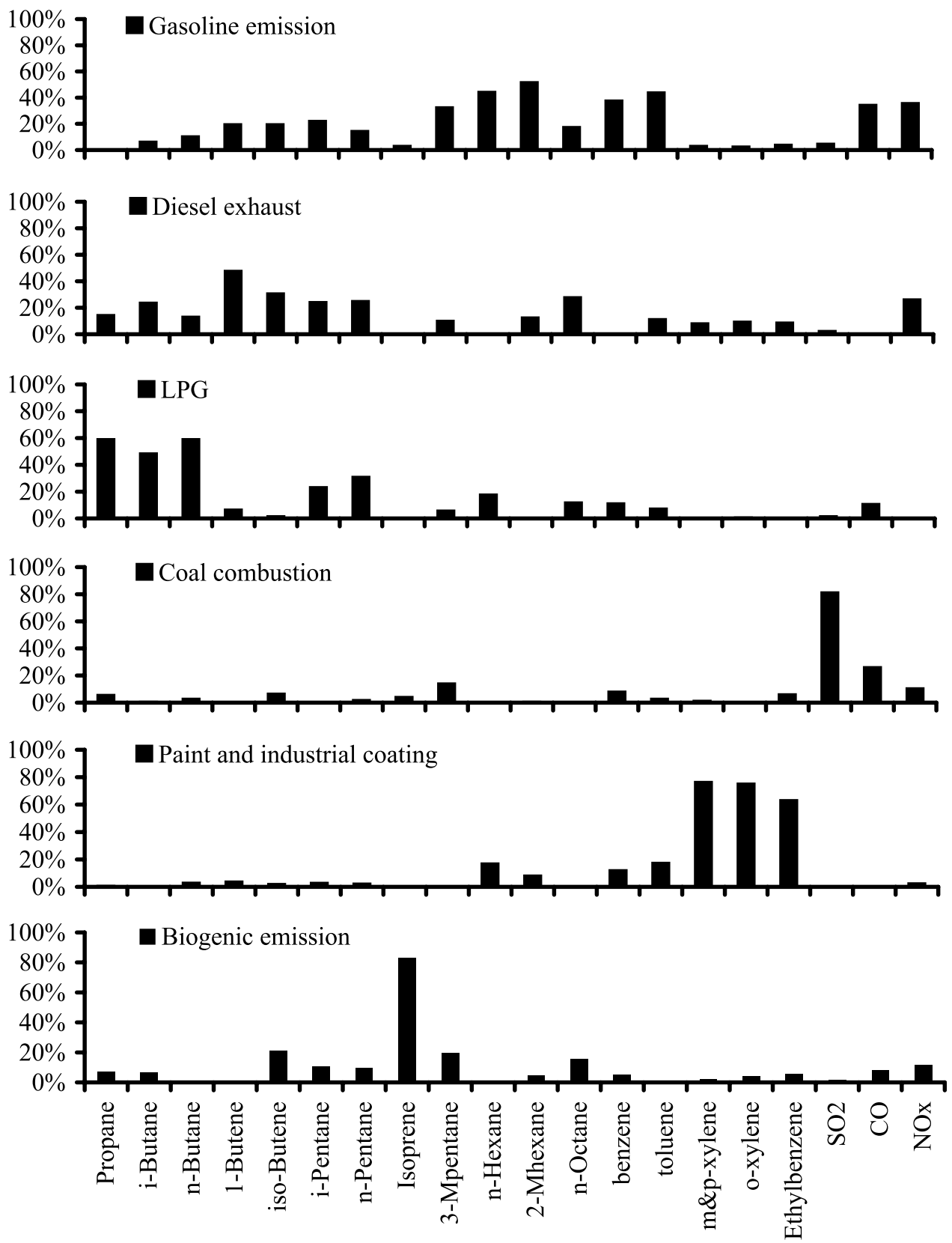

Figure 4. Explained variation of six identified sources at Yufa.

daytime may be offset by the increase in mixing layer height, leading to a roughly consistent source contribution throughout the day. Diesel exhaust exhibits two peaks during the rush hours from 0900 to 1000 LT and from 1600 to 2000 LT, indicating that the increase in emission level from buses during rush hour more than offsets the dilution caused by the mixing height increase. LPG shows two peaks, one in the afternoon and one in the evening, which correspond well with the lunch and dinner meal times of increased domestic cooking activities. Contribution from coal combustion is in line with the diurnal variation of power supply, which is directly related to the coal consumption and $\mathrm{SO}_{2}$ emission. Fugitive industrial coating and architectural paint sources exhibit variation similar to most of the sources at Yufa, indicating consistent diurnal emissions as mentioned in previous discussions. Different from the diurnal pattern at
Yufa, the contribution of biogenic emission at PKU is relatively consistent during the daytime with no significant peak observed. Apart from the dilution effects of the mixing height increase, the enhanced chemical loss of isoprene caused by the increased presence of ambient hydroxyl radical in urban Beijing prevents biogenic contribution from increasing further in the late morning hours [Lee and Wang, 2006].

[26] The exploration of diurnal variation characteristics is an advantage of an online VOC analyzer with a higher temporal resolution. It illustrates that high-resolution VOC measurements, especially those with a sampling frequency on the scale of less than 1 day, combined with PMF, can make a strong contribution to our understanding of pollutant emissions and transport characteristics, and is a useful tool with which to formulate effective pollution control strategies. Interpretability of the diurnal characteristics of different 
Table 3. Averaged Absolute Source Contribution and Contribution Percentages at the PKU and Yufa Site

\begin{tabular}{lcccc}
\hline & $\begin{array}{c}\text { PKU } \\
\text { Concentration } \\
(\mathrm{ppbv})\end{array}$ & $\begin{array}{c}\text { PKU } \\
(\%)\end{array}$ & $\begin{array}{c}\text { Yufa } \\
\text { Concentration } \\
(\mathrm{ppbv})\end{array}$ & $\begin{array}{c}\text { Yufa } \\
(\%)\end{array}$ \\
\hline $\begin{array}{l}\text { Gasoline exhaust } \\
\text { Evaporated and liquid }\end{array}$ & 5.9 & 27 & $3.1^{\mathrm{a}}$ & $25^{\mathrm{a}}$ \\
$\quad$ gasoline & 6.7 & 30 & & \\
Diesel exhaust & 1.2 & 5 & 1.7 & 14 \\
LPG & 2.9 & 13 & 4.6 & 37 \\
Coal combustion & 1.2 & 6 & 0.4 & 3 \\
Paint and industrial coating & 3.5 & 16 & 1.8 & 14 \\
Biogenic emission & 0.66 & 3 & 1.0 & 8 \\
Total & 22.1 & & 12.5 & \\
\hline
\end{tabular}

${ }^{\mathrm{a}}$ Values combine gasoline exhaust and evaporated and liquid gasoline.

sources could give us additional confidence in the reliability of the source apportionment results.

\section{Directional Dependence of Sources}

[27] In this section we investigate the relationship between source contribution and wind direction and speed. The wind rose map of all the derived sources at PKU and Yufa is illustrated in Figure 6. A wind rose map is a diagram that summarizes wind information at a particular location over a specified time period. At a particular point on the wind rose map, wind direction is represented by the point angle and wind speed is represented by the radius. In Figure 6, the color in the wind rose is a metric for the average $\mathrm{PM}_{2.5}$ concentration at the monitoring site, while the concentric circles represent wind speeds, at $2 \mathrm{~m} / \mathrm{s}$ intervals. The red contour in the last plot of Figures $6 \mathrm{a}$ and $6 \mathrm{~b}$ shows the $80 \%$ frequency of occurrence of winds at particular speeds and directions. If a pollution hot spot is located outside the contour on the wind rose map, it can be regarded as sporadic outlier that does not impose significant influence over the averaged source contribution. Detailed information about wind rose maps is given by A. K. H. Lau et al. (Significant marine source for $\mathrm{SO}_{2}$ level in Hong Kong, 2005, available at http://www.civic-exchange.org/eng/upload/files/ 200506 MarineSourceSO2.pdf). It is worth to note that local wind measurement may or may not be representative of the mesoscale transport, so the wind rose plots are more accurate to identify emissions from nearby sources.

\subsection{Yufa Site}

[28] A first glance at all six wind roses of Yufa reveals a notable northeast-southwest extension, which implies a typical source alignment in the Beijing area. This spatial pattern is also consistent with the satellite images of AOD distribution. Gasoline emission is associated with weak northwesterly winds and diesel exhaust is associated with a more widespread northwesterly to northeasterly winds. This indicates they are mainly from urban Beijing. A large percentage of VOC is from LPG emission (37\%), and this is mainly associated with the weak northeasterly wind in the morning, originating from the Yufa town.

[29] Two area sources are responsible for the industrial coating and architectural paint source at Yufa, one is wider and from the north possibly urban Beijing, the other is narrower and from the south possibly Gu'an city $10 \mathrm{~km}$ south of Yufa. Coal combustion and biogenic emission are both associated primarily with southwesterly winds, suggesting widespread emission in Hebei province. Isoprene is highly reactive in the atmosphere, so the main source is expected to be close and to the southwest direction. It is worth noting that the magnitudes of coal combustion and biogenic emission are low, implying that regional transportation is not very important for the VOC levels observed at Yufa in August and September 2006. We believe that during pollutant transportation, most of the reactive VOCs have been depleted, with secondary species such as ozone and sulfate formed and then transported to Beijing.

\subsection{PKU Site}

[30] Before discussing the source directional dependence at PKU, it is worth noting that the wind data was collected

Table 4. Summary of Contribution Percentages of Vehicle-Related Sources to Ambient VOC in Different Cities in the World

\begin{tabular}{|c|c|c|c|c|}
\hline Paper & Sampling Site & Sampling Period & $\begin{array}{c}\text { Source } \\
\text { Apportionment } \\
\text { Model }\end{array}$ & $\begin{array}{c}\text { Vehicle-Related } \\
\text { Contribution } \\
\text { Percentage }\end{array}$ \\
\hline \multirow{2}{*}{$\begin{array}{l}\text { Jorquera and Rappengluck } \\
\text { [2004] }\end{array}$} & Downtown Santiago, Chile & November and December 1996 & PMF/Unmix & $75.8 \pm 5.6 \%$ \\
\hline & Residential area Santiago, Chile & November and December 1996 & PMF/Unmix & $68.4 \pm 4.1 \%$ \\
\hline Latella et al. [2004] & Urban site in Milan, Italy & 13 September to 1 October 2003 & $\mathrm{PMF} / \mathrm{CMB}$ & $60-80 \%$ \\
\hline Liu et al. [2005] & Six sites in Beijing, China & 2002 and 2003 & $\mathrm{CMB}$ & $\begin{array}{l}69 \% \text { in winter, } \\
78 \% \text { in summer }\end{array}$ \\
\hline \multirow[t]{3}{*}{ Srivastava et al. [2005] } & $\begin{array}{l}\text { Traffic intersections of } \\
\text { Delhi, India }\end{array}$ & August 2001 to July 2002 & $\mathrm{CMB}$ & $82-87 \%$ \\
\hline & Commercial sites of Delhi, India & August 2001 to July 2002 & $\mathrm{CMB}$ & $73-76 \%$ \\
\hline & Residential sites of Delhi, India & August 2001 to July 2002 & $\mathrm{CMB}$ & $40-56 \%$ \\
\hline Buzcu and Fraser [2006] & $\begin{array}{l}\text { Three sites in the Houston Ship } \\
\text { Channel, TX }\end{array}$ & 2 June to 31 October 2003 & PMF & $17-29 \%$ \\
\hline Xie and Berkowitz [2006] & $\begin{array}{l}\text { Five sites in the Houston Ship } \\
\text { Channel, TX }\end{array}$ & 1 June to 31 October 2003 & PMF & $7-25 \%$ \\
\hline \multirow[t]{2}{*}{ Brown et al. [2007] } & Azusa, Los Angeles, CA & $\begin{array}{l}\text { July to September, } \\
2001 \text { to } 2003\end{array}$ & $\mathrm{PMF} / \mathrm{CMB}$ & $80 \%$ \\
\hline & Hawthorne, Los Angeles, CA & $\begin{array}{l}\text { July to September, } \\
2001 \text { to } 2003\end{array}$ & $\mathrm{PMF} / \mathrm{CMB}$ & $71 \%$ \\
\hline \multirow[t]{3}{*}{ Liu et al. [2008] } & Guangzhou (urban site), China & 4 October to 3 November 2004 & $\mathrm{CMB}$ & $74.5 \pm 5.3 \%$ \\
\hline & Xinken (rural site), China & 4 October to 3 November 2004 & $\mathrm{CMB}$ & $42.6 \pm 9.2 \%$ \\
\hline & Dongguan (industrial site), China & 4 October to 3 November 2004 & $\mathrm{CMB}$ & $48.3 \pm 3.6 \%$ \\
\hline Song et al. [2008] & Peking University, Beijing, China & 1 to 27 August 2005 & PMF/Unmix/CMB & $52-64 \%$ \\
\hline
\end{tabular}


Gasoline emission

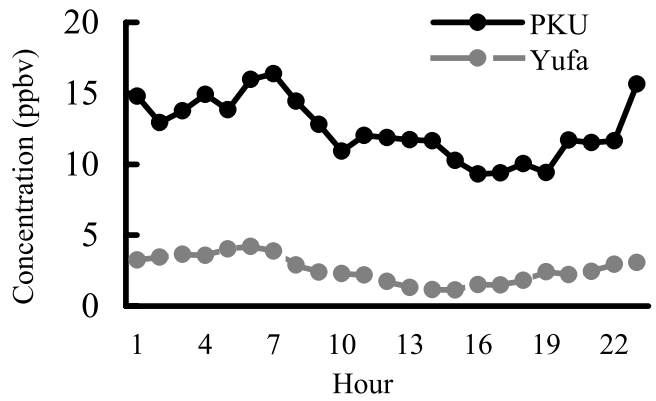

LPG

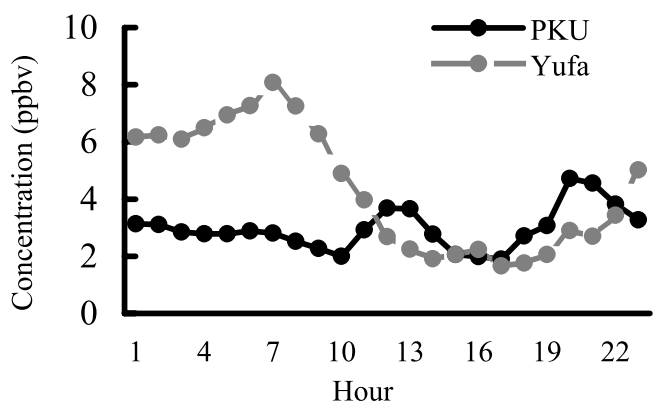

Paint and industrial coating

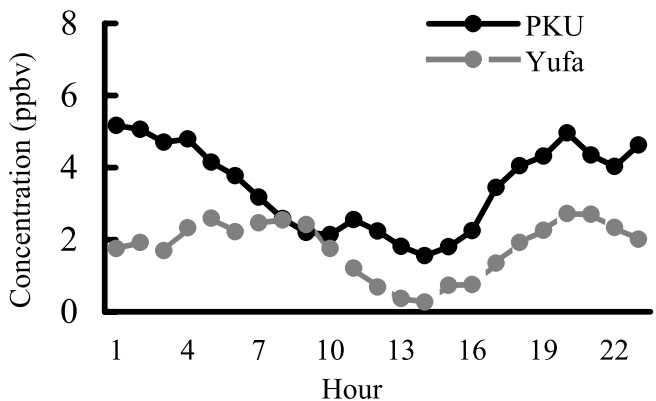

Diesel exhaust

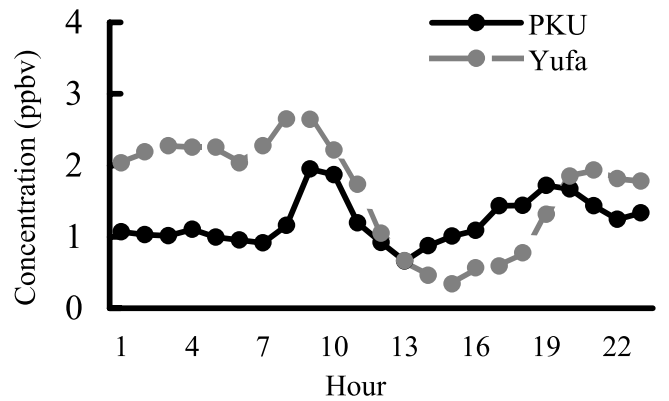

Coal combustion

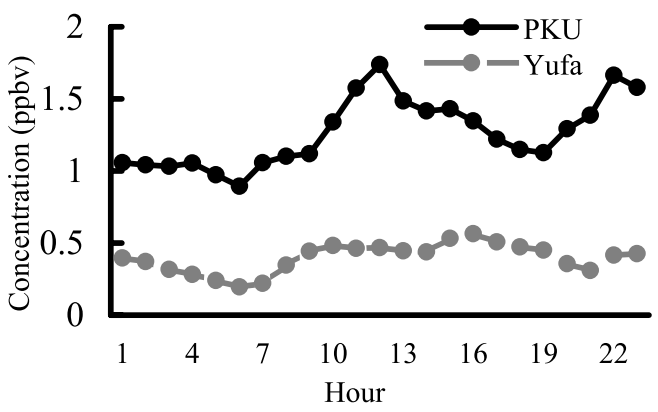

Biogenic emission

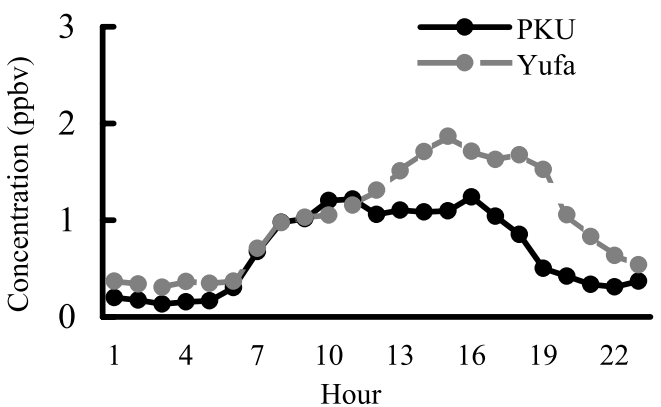

Total VOC

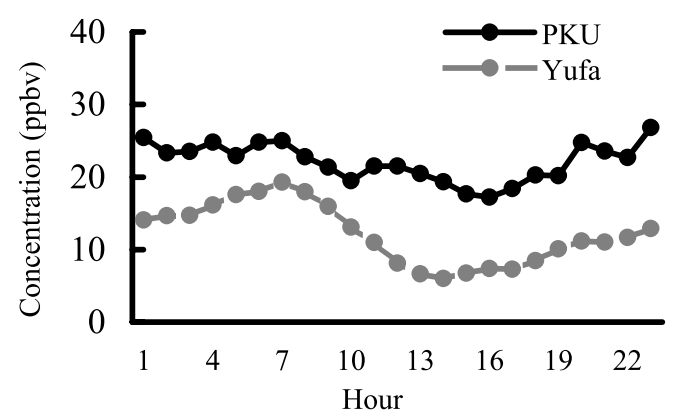

Figure 5. Diurnal variations of all identified sources and total VOC at PKU and Yufa.

at the top of the five-storey Physics Building at PKU which is around $200 \mathrm{~m}$ northeast of the building where the VOC samples were collected. There is a busy road (Zhongguancun Street) in between the wind and pollutant monitoring locations. In addition, the recorded average wind speed at PKU is much lower than that of Yufa.
[31] As shown in Figure 6, the directional dependences at PKU are not as clear as those at Yufa. This is probably a result of the irregular turbulence caused by the complicated underlying surface in urban Beijing. Vehicle-related sources are associated with almost all wind directions when the wind speed is less than $2 \mathrm{~m} / \mathrm{s}$. LPG also shows a wide wind 

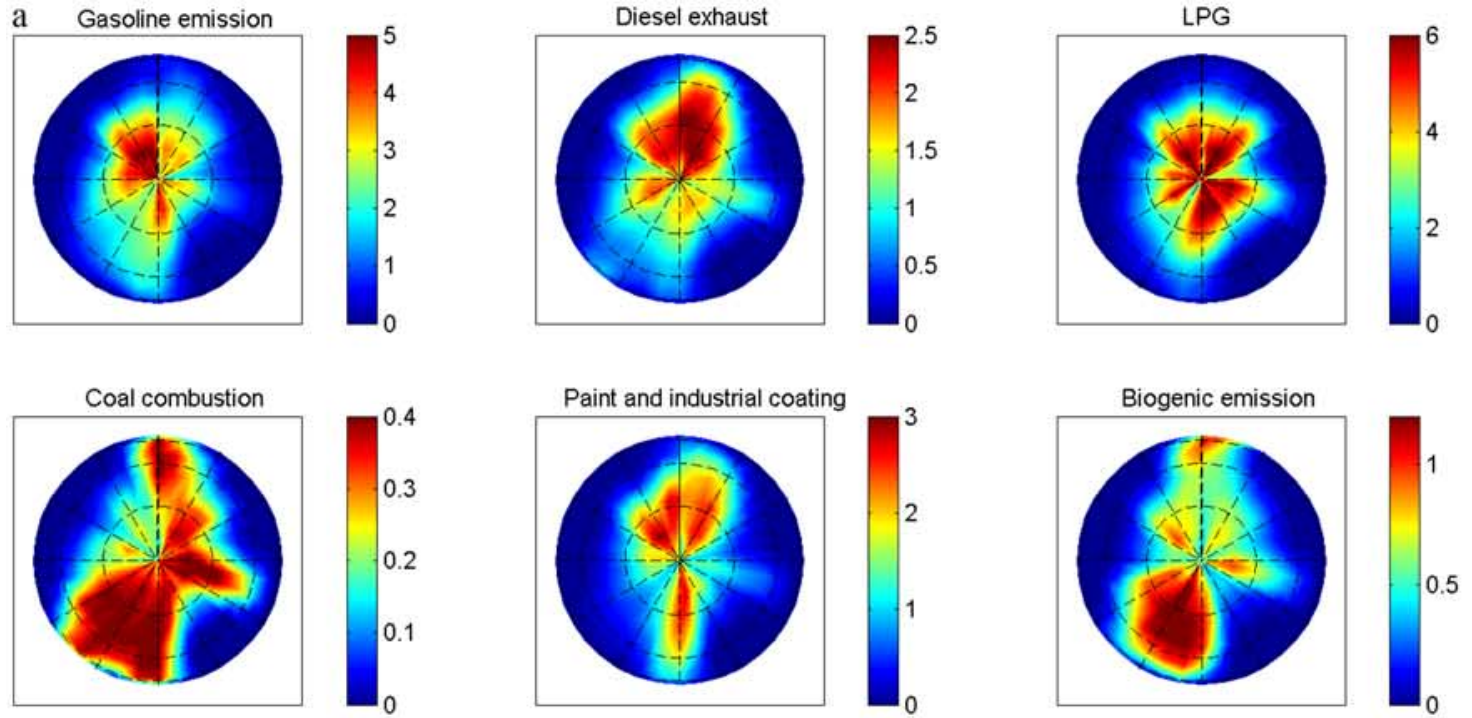

$80 \%$ wind frequency contour
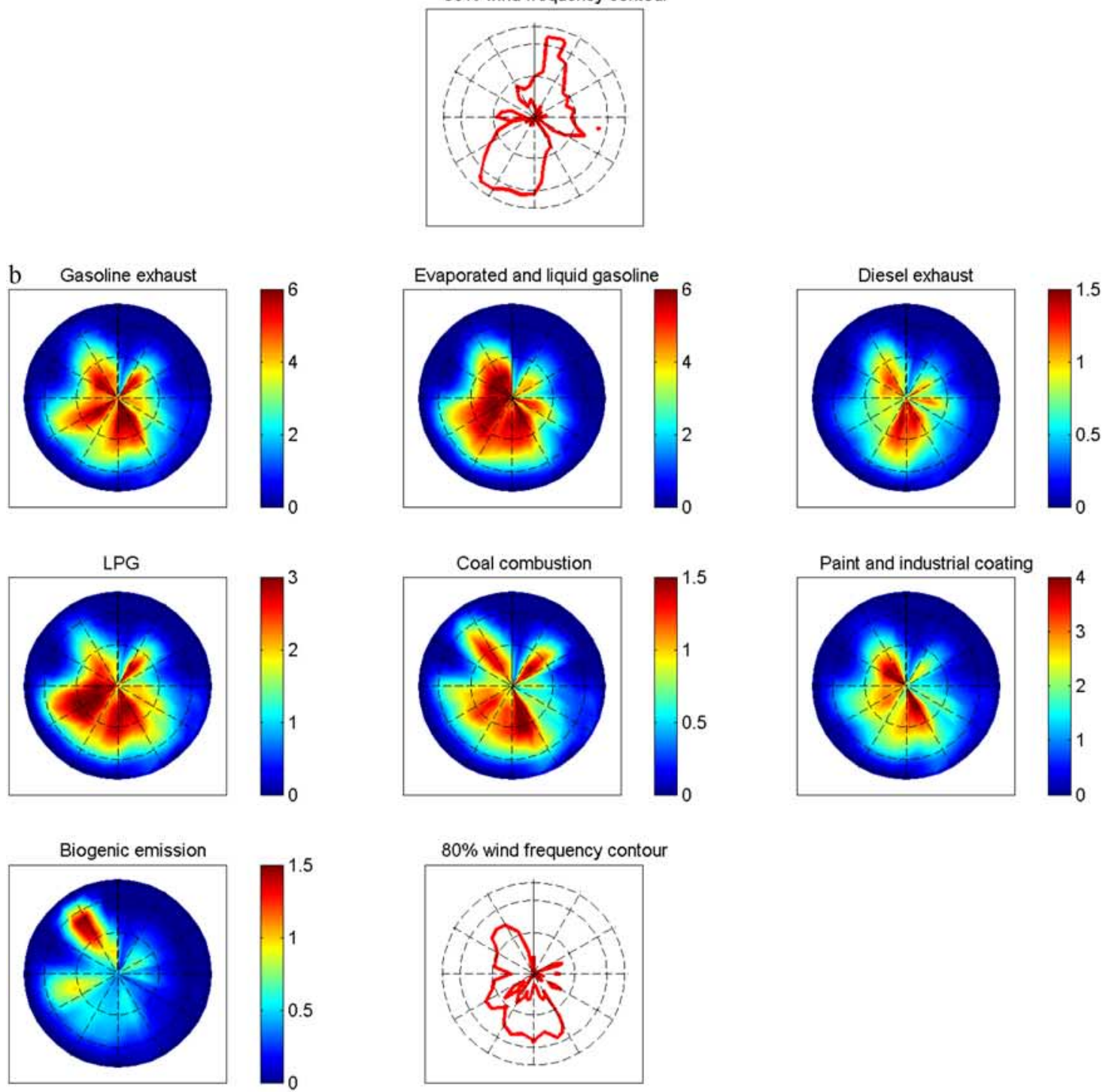

Figure 6. Wind rose maps of identified sources at (a) Yufa and (b) PKU (unit: ppbv). 
rose mainly from the southwest and southeast, pointing to the city center direction. For coal combustion, industrial coating and architectural paint, the wind roses are relatively narrower, with two major source directions being northwesterly and southeasterly. Differing from the results at Yufa, biogenic emissions at the PKU site are associated with northwesterly winds with speed of $2-4 \mathrm{~m} / \mathrm{s}$. In the northwest of PKU, there are some mountainous areas with abundant vegetation coverage.

\section{Ozone Forming Potential}

[32] The ultimate goal of VOC source identification is to formulate effective control strategy, especially for ozone. The prevailing VOC control strategies worldwide are all mass-based. However, it was found that the mass of VOCs is less correlated with the photochemical ozone formation, compared with the reactivity of VOCs. For example, a serious problem of the mass-based VOC control was highlighted when the California Air Resource Board's Regulation for Reducing the Ozone Formed from Aerosol Coating Product Emissions was formerly implemented [Avery, 2006]. In addition, receptor modeling researches [Russell et al., 1995; Derwent et al., 2007] demonstrated that the reactivity-based VOC control was more effective than the mass-based one to abate the smog problem in the United States and Europe, by means of substituting lower reactive compounds for higher reactive compounds in air quality modeling study.

[33] Therefore, source contribution to ambient ozone formation should be evaluated in a reactivity base. The ozone forming potential derived from each source is calculated by summing up the products of the calculated individual VOC and $\mathrm{CO}$ concentrations and the corresponding Maximum Incremental Reactivity (MIR) coefficients [Carter, 1994]. As Beijing is a typical VOC-sensitive area to ozone formation [Xu et al., 2008], we believe MIR coefficient is the most suitable scale to describe VOC reactivity in Beijing. We also understand that there are some species our study did not cover, such as $\mathrm{CH}_{4}$, some alkenes, and oxidized VOC (OVOC), that are able to contribute to ozone formation during their reaction with $\mathrm{OH}$. The primary OVOC emission is far less than the primary VOC emission, so this may be considered negligible. However, the amount of alkenes emitted from combustion processes in vehicles and $\mathrm{CH}_{4}$ emissions from biogenic sources cannot be ignored, causing a possible underestimation of the ozone forming potential for vehicular-related sources and biogenic emission, and an overestimation of the ozone from paints, if only VOC species are considered.

[34] Figure 7 shows the source-specific ozone forming potential at both PKU and Yufa. At PKU, vehicle-related sources, which accounts for $62 \%$ of VOC loadings at PKU, contribute to $55 \%$ of the locally generated ozone. This illustrates that the VOC emission from vehicles and related sources are of great importance in producing secondary pollutants at PKU. On the other hand, coal combustion is associated with $19 \%$ of the total ozone production, most of which is from CO. Industrial coating and architectural paint, rich in TEX, are responsible for $14 \%$ of the total ozone production.
[35] At Yufa, it is found that vehicle-related sources, most of which are from urban Beijing, accounts for $42 \%$ of the total ozone at Yufa, 13\% less than the percentage in urban Beijing. Coal combustion, industrial coating and architectural paint exhibit similar percentages of total ozone production as at PKU. With a $37 \%$ contribution to the total VOC, LPG only accounts for $15 \%$ of the total ozone forming potential. This is however much larger than the PKU percentage of $4 \%$. On the contrary, with $8 \%$ contribution to the total VOC, biogenic emission accounts for $12 \%$ of the total ozone forming potential at Yufa.

[36] As discussed previously, a certain amount of ozone is produced during the transport of regionally emitted VOCs, such as coal combustion and biogenic emissions. Accompanying this VOC transformation, the produced ozone could be transported to the monitoring site, therefore enhancing ozone contribution. A detailed identification of regional VOC emissions transported to Beijing requires a comprehensive monitoring campaign in the upwind (southwesterly) direction covering locations from Beijing all the way to the border between Hebei and Henan provinces.

\section{Conclusions and Future Recommendations}

[37] This is the first-ever source apportionment study of VOC species collected simultaneously in rural and urban locations of a Chinese city. The online VOC measurement with a finer temporal resolution has proven capable of providing substantially more information than canisterbased VOC measurement could. In this study, an advanced receptor model, Positive Matrix Factorization, was utilized to extract detailed information from the source apportionment results to better understand the VOC characteristics in August in Beijing.

[38] The main feature of VOC sources in Beijing is that a significant fraction of identified VOC sources are related to vehicular activities, which specifically contribute $62 \%$ to VOC loading and $55 \%$ to ozone forming potential at the PKU site, and $38 \%$ to VOC loading and $42 \%$ to ozone forming potential at Yufa. Therefore, controlling vehicle emissions should be a top priority for VOC reduction in Beijing. Since installing a bifuel supply system for engines has been proven not to work well, replacing the gasolineand diesel-fueled vehicles with LPG or natural gas vehicles seems to be the most effective method of reducing VOC emissions while also reducing ozone forming potential.

[39] LPG used for domestic cooking also contributed significantly to VOC emission at both sites, especially at Yufa (37\%). It is concluded that a significant LPG impact mainly occurs in the mornings when the local wind is blowing from the northeast, bringing VOC emitted from the Yufa town to the site. Local sources within Beijing territory contributed to most of the ambient VOC recorded at the PKU and Yufa sites. As some of the VOC species are quite reactive, we believe that VOCs emitted from distant sources have been depleted during transportation, along with the formation of secondary pollutants, such as ozone and sulfate. Therefore, a detailed identification of regional VOC emissions that are transported to Beijing requires a comprehensive monitoring campaign in the upwind (southwesterly) direction. Satellite images of the spatial distribution of 


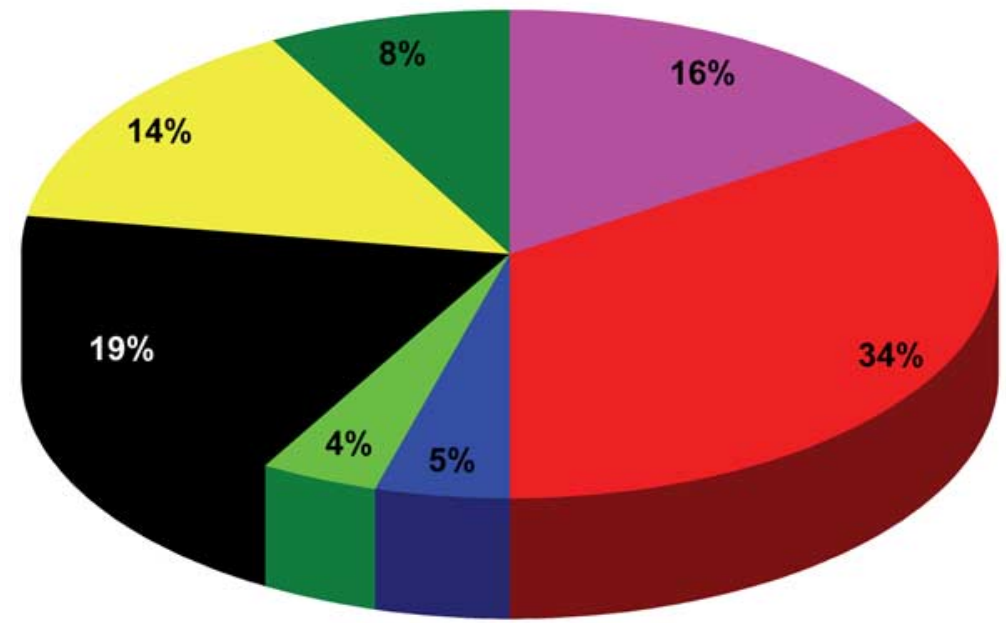

Gasoline exhaust

Evaporated and liquid gasoline

Diesel exhaust

LPG

- Coal combustion

Paint and Industrial Coating

- Biogenic emission

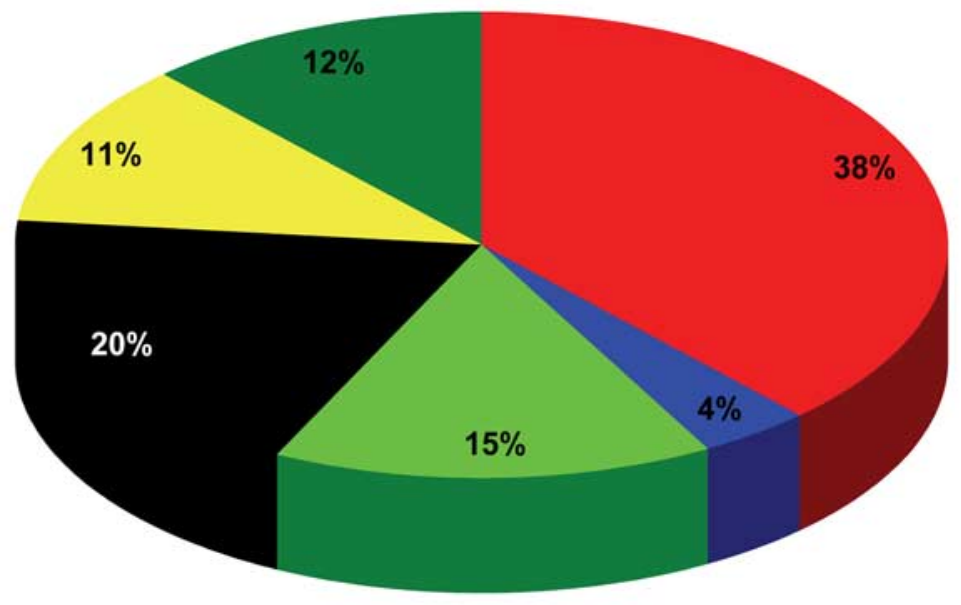

Easoline emission

Diesel exhaust

- $\mathrm{EPG}$

- Coal combustion

Paint and industrial coating

Biogenic emission

Figure 7. Source-specific contribution percentages of ozone forming potential for (top) PKU and (bottom) Yufa.

the surface extinction coefficient revealed this northeastsouthwest pollution band extending from Beijing to central Henan province (Figure 1). Comprehensive monitoring of $\mathrm{VOC}$ and other types of pollutants are recommended to cover this pollution band.

[40] Diurnal variation analysis revealed that verticalintegrated VOC source contribution at Yufa is relatively consistent throughout the day. Variation of the mixing height is the limiting factor controlling the ground-level VOC concentration in rural areas. While in urban areas, a similar control occurs for industrial coating and architectural paint, but not for diesel exhaust whose contributions are mainly concentrated in the morning and evening peak hours. The ability to explore diurnal variation characteristics is an advantage of an online VOC analyzer with a higher temporal resolution. This study illustrates that high-resolution VOC measurements, especially those with a sampling frequency on the scale of less than 1 day, combined with PMF, can make a strong contribution to our understanding of pollut- ant emissions and transport characteristics, and is a useful tool with which to formulate effective pollution control strategies.

[41] The ultimate goal of VOC source identification is to formulate effective control strategy, especially for ozone. In this regard, reactivity-based scale is more accurate than mass-based scale. To accurately estimate the ozone forming potential of VOC sources, a complete VOC emission spectrum is necessary. There are some important species, such as monoterpene and light alkenes, that are potentially key precursors to ozone formation. There may also be some halocarbons which are unique to certain industrial emissions. These species are suggested to cover in future monitoring schemes.

[42] Acknowledgments. We acknowledge the support from all parties involved in the project "Campaigns of Air Quality Research in Beijing and Surrounding Region 2006" (CAREBeijing-2006) led by Peking University. This work is also supported by the Research Grant Council of Hong Kong (615406). We thank the continuous interests of and 
financial support from the Civic Exchange of Hong Kong in our air quality research in Beijing and the Pearl River Delta region.

\section{References}

Avery, R. J. (2006), Reactivity-based VOC control for solvent products: More efficient ozone reduction strategies, Environ. Sci. Technol., 40, 4845-4850, doi:10.1021/es060296u.

Beijing Municipal Bureau of Statistics (BMBS) (2007), Beijing Statistical Yearbook 2007, China Stat. Press, Beijing. (Available at http:// www.bjstats.gov.cn/tjnj/2007-tjnj/index.htm)

Brown, S. G., A. Frankel, and H. R. Hafner (2007), Source apportionment of VOCs in the Los Angeles area using positive matrix factorization, Atmos. Environ., 41, 227-237, doi:10.1016/j.atmosenv.2006.08.021.

Buzcu, B., and M. P. Fraser (2006), Source identification and apportionment of volatile organic compounds in Houston, TX, Atmos. Environ., 40, 2385-2400, doi:10.1016/j.atmosenv.2005.12.020.

Carter, W. P. L. (1994), Development of ozone reactivity scales for volatile organic compounds, J. Air Waste Manage. Assoc., 44, 881-889.

Derwent, R. G., M. E. Jenkin, N. R. Passant, and M. J. Piling (2007), Reactivity-based strategies for photochemical ozone control in Europe, Environ. Sci. Policy, 10, 445-453, doi:10.1016/j.envsci.2007.01.005.

Fujita, E. M. (2001), Hydrocarbon source apportionment for the 1996 Paso del Norte ozone study, Sci. Total Environ., 276, 171-184, doi:10.1016/ S0048-9697(01)00778-1.

Guinot, B., J.-C. Roger, H. Cachier, P. C. Wang, J. H. Bai, and T. Yu (2006), Impact of vertical atmospheric structure on Beijing aerosol distribution, Atmos. Environ., 40, 5167-5180, doi:10.1016/j.atmosenv. 2006.03.051.

Hao, J. M., J. N. Hu, and L. X. Fu (2006), Controlling vehicular emissions in Beijing during the last decade, Transp. Res., Part A, 40, 639-651, doi: $10.1016 /$ j.tra.2005.11.005.

Huang, S., M. Shao, S. H. Lu, and Y. Liu (2008), Reactivity of ambient volatile organic compounds (VOCs) in summer of 2004 in Beijing, Chin. Chem. Lett., 19, 573-576, doi:10.1016/j.cclet.2008.03.029.

Jorquera, H., and B. Rappengluck (2004), Receptor modeling of ambient VOC at Santiago, Chile, Atmos. Environ., 38, 4243-4263, doi:10.1016/ j.atmosenv.2004.04.030.

Kesselmeier, J., and M. Staudt (1999), Biogenic volatile organic compounds (VOC): An overview on emission, physiology and ecology, J. Atmos. Chem., 33, 23-88, doi:10.1023/A:1006127516791.

Lanz, V. A., M. R. Alfarra, U. Baltensperger, B. Buchmann, C. Hueglin, and A. S. H. Prevot (2007), Source apportionment of submicron organic aerosols at an urban site by factor analytical modelling of aerosol mass spectra, Atmos. Chem. Phys., 7, 1503-1522.

Latella, A., G. Stani, L. Cobelli, M. Ducane, H. Junninen, C. Astorga, and B. R. Larsen (2004), Semicontinuous GC analysis and receptor modeling for source apportionment of ozone precursor hydrocarbons in Bresso, Milan, 2003, J. Chromatogr. A, 1071, 29-39, doi:10.1016/j.chroma. 2004.12.043.

Lee, B. S., and J. L. Wang (2006), Concentration variation of isoprene and its implications for peak ozone concentration, Atmos. Environ., 40, 5486-5495, doi:10.1016/j.atmosenv.2006.03.035.

Li, Z., P. K. Hopke, L. Husain, S. Qureshi, V. A. Dutkiewicz, J. J. Schwab, F. Drewnick, and K. L. Demerjian (2004), Sources of fine particle composition in New York City, Atmos. Environ., 38, 6521-6529, doi:10.1016/j.atmosenv.2004.08.040.

Liu, Y., M. Shao, J. Zhang, L. L. Fu, and S. H. Lu (2005), Distributions and source apportionment of ambient volatile organic compounds in Beijing City, China, J. Environ. Sci. Health, Part A, 40, 1843-1860.

Liu, Y., M. Shao, S. H. Lu, C. C. Chang, J. L. Wang, and L. L. Fu (2008), Source apportionment of ambient volatile organic compounds in the Pearl River Delta, China: Part II, Atmos. Environ., 42, 6261-6274, doi:10.1016/j.atmosenv.2008.02.027.

Mukund, R., T. J. Kelly, and C. W. Spicer (1996), Source attribution of ambient air toxic and other VOCs in Columbus, Ohio, Atmos. Environ., 30, 3457-3470, doi:10.1016/1352-2310(95)00487-4.

$\mathrm{Na}, \mathrm{K}$., and Y. P. Kim (2007), Chemical mass balance receptor model applied to ambient $\mathrm{C}_{2}-\mathrm{C}_{9}$ VOC concentration in Seoul, Korea: Effect of chemical reaction losses, Atmos. Environ., 41, 6715-6728, doi:10.1016/j.atmosenv.2007.04.054

Na, K., Y. P. Kim, I. Moon, and K. C. Moon (2004), Chemical composition of major VOC emission sources in the Seoul atmosphere, Chemosphere, 55, 585-594, doi:10.1016/j.chemosphere.2004.01.010.

Paatero, P. (2000), User's Guide for Positive Matrix Factorization Programs PMF2 and PMF3, Part 1: Tutorial, Univ. of Helsinki, Helsinki.

Russell, A., J. Milford, M. S. Bergin, L. McNair, Y. Yang, W. R. Stockwell, and B. Croes (1995), Urban ozone control and atmospheric reactivity of organic gases, Science, 269, 491-495, doi:10.1126/science. 269.5223.491

Scheff, P. A., and R. A. Wadden (1993), Receptor modeling of volatile organic compounds. 1. Emission inventory and validation, Environ. Sci. Technol., 27, 617-625, doi:10.1021/es00041a005.

Seila, R. L., H. H. Main, J. L. Arriaga, G. V. Martinez, and A. B. Ramadan (2001), Atmospheric volatile organic compounds measurements during the 1996 Paso del Norte ozone study, Sci. Total Environ., 276, 153-169, doi:10.1016/S0048-9697(01)00777-X.

Shao, M., L. L. Fu, Y. Liu, S. H. Lu, Y. H. Zhang, and X. Y. Tang (2005), Major reactive species of ambient volatile organic compounds (VOCs) and their sources in Beijing, Dokl. Earth Sci., 48, suppl. 2, 147-154.

Song, Y., M. Shao, Y. Liu, S. H. Lu, W. Kuster, P. Goldan, and S. D. Xie (2007), Source apportionment of ambient volatile organic compounds in Beijing, Environ. Sci. Technol., 41, 4348-4353, doi:10.1021/es0625982.

Song, Y., W. Dai, M. Shao, Y. Liu, S. H. Lu, W. Kuster, and P. Goldan (2008), Comparison of receptor models for source apportionment of volatile organic compounds in Beijing, China, Environ. Pollut., 156, 174-183, doi:10.1016/j.envpol.2007.12.014.

Srivastava, A., B. Sengupta, and S. A. Dutta (2005), Source apportionment of ambient VOCs in Delhi City, Sci. Total Environ., 343, 207-220, doi:10.1016/j.scitotenv.2004.10.008.

Streets, D. G., et al. (2007), Air quality during the 2008 Beijing Olympic Games, Atmos. Environ., 41, 480-492, doi:10.1016/j.atmosenv. 2006.08.046.

Tang, X. Y. (2004), The characteristics of urban air pollution in China, in Urbanization, Energy, and Air Pollution in China, pp. 47-54, Natl. Acad. Press, Washington, D. C.

Wang, J. L., G. Z. Din, and C. C. Chan (2004), Validation of a laboratoryconstructed automated gas chromatograph for the measurement of ozone precursors through comparison with a commercial analogy, J. Chromatogr. A, 1027, 11-18, doi:10.1016/j.chroma.2003.08.099.

Watson, J. G., J. C. Chow, and E. M. Fujita (2001), Review of volatile organic compound source apportionment by chemical mass balance, Atmos. Environ., 35, 1567-1584, doi:10.1016/S1352-2310(00)00461-1.

Xie, X., M. Shao, Y. Liu, S. H. Lu, C. C. Chang, and Z. M. Chen (2008), Estimation of initial isoprene contribution to ozone formation potential in Beijing, China, Atmos. Environ., 42, 6000-6010, doi:10.1016/j.atmosenv. 2008.03.035.

Xie, Y. L., and C. M. Berkowitz (2006), The use of positive matrix factorization with conditional probability functions in air quality studies: An application to hydrocarbon emissions in Houston, Texas, Atmos. Environ., 40, 3070-3091, doi:10.1016/j.atmosenv.2005.12.065.

Xu, J., Y. H. Zhang, J. S. Fu, S. Q. Zheng, and W. Wang (2008), Process analysis of typical summertime ozone episodes over the Beijing area, Sci. Total Environ., 399, 147-157, doi:10.1016/j.scitotenv.2008.02.013.

Yao, X. H., A. P. S. Lau, M. Fang, C. K. Chan, and M. Hu (2003), Size distributions and formation of ionic species in atmospheric particulate pollutants in Beijing, China: 2-Dicarboxylic acids, Atmos. Environ., 37, 3001-3007, doi:10.1016/S1352-2310(03)00256-5.

A. K. H. Lau and Z. Yuan, Environmental Central Facility, Institute for the Environment, Hong Kong University of Science and Technology, Clear Water Bay, Hong Kong. (alau@ust.hk)

S. C. Liu, Research Center for Environmental Changes, Academia Sinica, Taipei 115, Taiwan.

P. K. K. Louie, Hong Kong Environmental Protection Department, 33/F, Revenue Tower, 5 Gloucester Road, Wanchai, Hong Kong.

M. Shao and T. Zhu, College of Environmental Sciences and Engineering, Peking University, Beijing 100871, China. (mshao@pku.edu.cn) 